\title{
“CARDOZO'S FOOT": THE CHANCELLOR'S CONSCIENCE AND CONSTRUCTIVE TRUSTS
}

\author{
H. JEFFERSON POWELL*
}

\section{INTRODUCTION}

About 350 years ago, the English legal scholar John Selden articulated the classic common-lawyer's complaint about the chancery's exercise of jurisdiction in equity. Selden remarked in his Table Talk, ${ }^{1}$

\begin{abstract}
Equity is A Roguish thing, for Law wee have a measure know what to trust too. Equity is according to the conscience of him that is Chancellor, and as that is larger or narrower soe is equity. Tis all one as if they should make the Standard for the measure wee call A foot, to be the Chancellors foot; what an uncertain measure would this be; One Chancellor has a long foot another A short foot a third an indifferent foot; tis the same thing in the Chancellors Conscience. ${ }^{2}$
\end{abstract}

The "Chancellor's foot" has since become proverbial shorthand for the argument that equity is an unjustified and unfortunate interference in the regular course of the rule of law. ${ }^{3}$

Selden's criticism went to the heart of equity's historic claim to legitimacy, the claim (originally made by Aristotle) that because law deals with general principles and is universally applicable, it necessarily will work injustice in some individual cases. ${ }^{4}$ The chancellor's jurisdiction, the argument went, is justified

Copyright $\odot 1993$ by Law and Contemporary Problems

* Professor of Law, Duke University.

I wrote this article while a visitor at the University of North Carolina School of Law; I am deeply grateful for Dean Judith Wegner's personal and institutional support. Thanks also to Tom Shaffer and to the participants in the Modern Equity symposium for their comments and criticisms.

1. The Table Talk, compiled from Selden's private conversations by a secretary, was published in 1689 , several decades after his death. See Edward Fry, Life of John Selden, in TABLE TALK OF JOHN SELDEN 177 (Frederick Pollock ed., 1927) [hereinafter TABLE TALK].

2. Id. at 43. I have silently spelled out abbreviated words and replaced the obsolete thorns with "th," but have otherwise left Selden's words as Pollock edited them.

3. Selden's critique of equity, and his metaphorical expression of that critique, were influential in the early modern "settlement of the principles of equity." WILLIAM HOLDSWORTH, SOME MAKERS OF ENGLISH LAw 198 (1938). See, e.g., Gee v. Pritchard, 36 Eng. Rep. 670, 674 (Chan. 1818) (Lord Eldon) ("The doctrines of this Court ought to be as well settled and made as uniform almost as those of the common law, laying down fixed principles, but taking care that they are to be applied according to the circumstances of each case. I cannot agree that the doctrines of this Court are to be changed with every succeeding judge. Nothing would inflict on me greater pain, in quitting this place, than the recollection that I had done any thing to justify the reproach that the equity of this Court varies like the Chancellor's foot.").

4. "Since adherence to principles of 'law' does not invariably produce justice, equity is necessary." Simonds v. Simonds, 380 N.E.2d 189, 192 (N.Y. 1978) (citing Aristotle). 
because, by his discretion to see justice done in individual cases, the chancellor can remedy the imperfect fit between the rules of law and the facts of the world. ${ }^{5}$ "Universality of law requires equity." All of this, Selden asserted, was a cover for the imposition of one person's private moral perspectives on those brought before him, as wayward and uncontrollable as claims to private religious inspiration: "Equity in Law is the same that the spirit is in Religion, whatever one pleases to make it. Some times they Goe according to conscience some time according to Law some time according to the Rule of the Court." "The displacement of the known rules of the (common) law by the chancellor's exercise of conscience, in Selden's view, rendered legal rights and liabilities uncertain ("for Law wee ... know what to trust"), and dependent on the moral character and wisdom (and the politics) of the individual who happens at any given moment to be chancellor. ${ }^{8}$

Selden's complaints about the role of conscience and discretion in the decisions of chancery courts have persisted even as the distinction between rulegoverned law and discretionary equity has become ever less clear. ${ }^{9}$ On the level of form, equity and law no longer appear to involve different methodologies of decisionmaking. Modern equity jurisprudence has itself become a great body of equitable law, as complex, doctrinal, and rule-haunted as the common law ever was. ${ }^{10}$ Modern common law, on the other hand, is suffused with traditionally equitable invocations of fairness and conscientious behavior. ${ }^{11}$ Perhaps even

5. Sir Thomas More, one of the first lay chancellors and a distinguished common lawyer himself, explained to the common law judges angered over equity's interventions in legal proceedings that the fault lay in the common law courts' failure to avoid injustices.

Then offered he this unto them, that if the Justices of every court (unto whom the reformation of the rigour of the law, by reason of their office, most especially appertained) would, upon reasonable considerations, by their own discretions (as they were, he thought, in conscience bound), mitigate and reform the rigour of the law themselves, there should from thenceforth by him no more injunctions be granted. Whereunto when they refused to consdescend, then said he unto them, "Forasmuch as yourselves, my lords, drive me to that necessity for awarding out injunctions to relieve the people's injury, you cannot hereafter any more justly blame me."

William Roper, The Life of Sir Thomas More, Knight, in LIVES of SAINT ThOMAs More 23 (E.E. Reynolds ed., 1963).

6. Sharp v. Kosmalski, 351 N.E. 2d 721, 724 (N.Y. 1976).

7. TABLE TALK, supra note 1 , at 43.

8. Selden was deeply suspicious of arguments based on claims of individual conscience, in part because he saw no way rationally to decide between conflicting claims of conscience. See, for example, his discussion of what we would call acts of "conscientious objection" or "civil disobedience," id. at 35 ("who knows what inconvenyency may follow" from recognizing the validity of such claims). Selden's dislike for chancery's invocation of conscience probably stemmed as well from his lively awareness of the political forces that influence judges. See, e.g., id. at 60 ("we see the Judges look big, look like lions, but we do not see who moves them").

9. I should note that I have the legal systems of the United States in mind in these remarks. Some modifications-although not, I think, transformative ones-would be necessary if I were to speak of other common law jurisdictions.

10. See, e.g., Austin W. ScotT \& William F. Fratcher, The Law of Trusts (4th ed. 1989). No criticism is intended of Scott and Fratcher's excellent treatise, which intelligently analyzes the state of the equitable law of trusts.

11. See, e.g., RESTATEMENT (SECOND) OF CONTRACTS (1979), with its frequent "black letter" directions to act to achieve justice or avoid injustice. 
more importantly, most observers of U.S. law, at least since the legal realists, have perceived the presence in practice, even in the ostensibly most inflexible of legal rules and doctrines, of discretion and moral choice. ${ }^{12}$ We apparently cannot escape from the question of the Chancellor's foot no matter which category, "law" or "equity," we apply. ${ }^{13}$

We can accept the argument that, both in form and in practice law and equity have become largely indistinguishable and yet find some special cause for concern, or at least interest, in the workings of conscience in what we still label equitable doctrines and decisions. Even with the considerable infusion of equitable considerations into the substance of much common law doctrine, the formulas of equity are more likely to incorporate overt calls for the exercise of discretion and the application of the decisionmaker's moral intuitions. ${ }^{14}$ "Equity cases are rich in examples of a fruitful merger of morality and law."15 Furthermore, the acknowledged presence of a degree of discretion and choice in the chancery judge accompanies the authority to invoke powers that are, bluntly, coercive, extraordinarily intrusive, and easily misused or abused. ${ }^{16}$ The role of moral choice - the meaning of "the Chancellor's conscience"-in modern equity deserves attention.

This article proposes to examine this issue by focusing on a particular doctrine of equity, the constructive trust, and on a seminal figure in the development of the modern U.S. understanding of constructive trusts, Benjamin Cardozo. Cardozo played a demonstrably central role in the evolution of the constructive trust in the United States from a substantive legal relationship to an independent judicial remedy, an evolution that distanced modern U.S. doctrine from its historical roots as well as from what seems still to be the predominant view in England. That evolution has also greatly emphasized the importance of conscience in decisions involving constructive trusts, a development for which Cardozo-or at least Cardozo's opinions-is largely responsible. The argument proceeds in four sections. Section II reviews briefly the history and current understanding of the concept of "constructive trust." Section III examines the

12. Different observers have attributed the existence of discretion in law to a variety of sources, from the "rule-scepticism" and "fact-scepticism" of the original legal realists, to the "indeterminacy thesis" of some contemporary critical legal scholars. The perception that law is not in some formal sense strongly rule-governed is not confined to lawyers on the left of the political spectrum. See, e.g., Richard A. Posner, The Problems of JurisprudenCe (1990).

13. Put another way, we no longer have such categories for any but historical-and history-related (see the Seventh Amendment)-purposes.

14. Compare ReSTATEMENT (SECOND) OF CONTRACTS \$ 346(1) (1979) ("The injured party has a right to damages for any breach . . . unless the claim for damages has been suspended or discharged.") with $\S 357(1)$ ("Subject to [a variety of] rules . . . an injunction against breach of a contract will be granted in the discretion of the court.").

15. Richard A. PoSner, Cardozo: A StUdy in RePUTATION 105 (1990).

16. See, e.g., Professor Dobbs's discussion of the "tracing" rule of constructive trust doctrine, under which a constructive trust may be imposed not only on the misappropriated property, but also on "property belonging in good conscience to the plaintiff because it is a product of or equated with his property." Dobbs observes, "[l]ike other powerful rules, this one is capable of abuse." DAN B. DOBBS, HANDBOOK ON THE LAW OF REMEDIES 242 (1973). 
extraordinary rhetorical role Cardozo's name and language play in modern U.S. constructive trust law. Section IV discusses Cardozo's own constructive trust opinions, as well as his general views on the role of equity in twentieth-century U.S. law. Section V explores Cardozo's significance to understanding the role of judicial choice and discretion in modern U.S. equity.

\section{II}

\section{The Past and Present of the U.S. Doctrine of Constructive TRUSTS}

Although both U.S. and English lawyers are familiar with the term "constructive trust," as is so often the case similar language disguises substantive differences. "English law has always thought of the constructive trust as an institution ... as opposed to the American attitude that the constructive trust is purely a remedial" device. ${ }^{17}$ The English constructive trust is a trust, or at least something very much like one $;^{18}$ as understood in most U.S. courts, the constructive trust is a remedy, available "wherever specific restitution in equity is appropriate on the facts." ${ }^{19}$ These divergent uses of the same term can be understood only in the light of the two societies' diverging legal histories.

As the name suggests, the notion of "constructive trust" was developed by equity lawyers and judges confronted with cases analogous to those involving express trusts but where there was no such trust or it was unenforceable. ${ }^{20}$ In Keech v. Sandford ${ }^{21}$ for example, the defendant was trustee for the youthful plaintiff; the trust res consisted of a lease of the profits of a public market. When the lessor refused to renew the trust's lease, the trustee procured a new lease for himself. The chancellor ordered the trustee to convey the lease to his beneficiary and to account for any profits. "I must consider this as a trust for the infant ... though I do not say there is a fraud in this case, yet he should rather have let it run out, than to have had the lease to himself." The chancellor

17. R.H. Maudsley, quoted in A.J. OAKLEY, CONSTRUCTIVE TRUSTS 2 (1978) (citations omitted). "The great development of constructive trust as a remedy aimed at unjust enrichment has taken place in this country [the United States], for most of our courts have freed the remedy of any necessary connection with fiduciary relationship." 1 GEORGE E. PALMER, LAW OF RESTITUTION 12 (1978). Many English observers would agree with Professor Palmer's description while demurring to his clear approval of the U.S. development. See, e.g., D.W.M. Waters, The English Constructive Trust: A Look into the Future, 19 VAND. L. REV. 1215, 1254 (1966) (noting that "[m]any English lawyers" see "only a vague equitable principle" in the U.S. trends, and "fear the evolution of a 'monster' on their own shores").

18. Professor Palmer believes that some recent English decisions, without acknowledging it, have abandoned the requirement that some sort of fiduciary relationship exist as a predicate for the implication of a constructive trust. 1 PALMER, supra note 17, at 8 (1990 Supp.). See, e.g., Chase Manhattan Bank N.A. v. Israel-British Bank (London) Ltd., [1981] L.R. Ch. 105. If that interpretation of the cases is correct, the statement in the text should be modified, perhaps by being put in the past tense.

19. DOBBS, supra note 16 , at 246.

20. On the history of the constructive trust, see 1 PALMER, supra note 17, at 9-16.

21. 25 Eng. Rep. 223 (Chan. 1726). 
conceded that this conclusion placed the trustee at a peculiar disadvantage, ${ }^{22}$ but reasoned that his decision was necessary to protect trust beneficiaries from trustee self-dealing: "[I]t is very proper that rule should be strictly pursued, and not in the least relaxed; for it is very obvious what would be the consequence of letting trustees have the lease, on refusal to renew to cestui que use."23

The decision in Keech stemmed from a perceived need to protect someone against the abuse of a fiduciary relationship. Other early decisions involved oral promises that were not directly enforceable because of the Statute of Frauds. ${ }^{24}$ The common denominator of the early cases, and of the mainstream of English decisions up to the present, is the presence of some sort of relationship of trust, reposed and accepted, that parallels the fiduciary relationship an express trust creates between the trustee and the beneficiary: In implying the existence of a "constructive" trust, the English chancery recognizes and gives legal efficacy to a relationship or "institution" that already exists. ${ }^{25}$ "In England the constructive trust is treated as a substantive principle of liability normally imposed where a fiduciary relationship exists." 26 Despite the efforts of English law reformers, most prominent among them the former Master of the Rolls, Lord Denning, ${ }^{27}$ the English constructive trust remains substantively linked to the factual presence of a confidential relationship. ${ }^{28}$

One consequence of the English understanding of the constructive trust is that it significantly curtails the scope within which a chancery court can exercise discretion. The court's primary focus, under the traditional English approach, must be on the presence or absence of evidence showing the existence of a quasifiduciary relationship and its abuse, not on the overall equities between plaintiff and defendant. ${ }^{29}$ English critics of the U.S. approach often point out the open-

22. "This may seem hard, that the trustee is the only person of all mankind who might not have the lease." Id.

23. Id.

24. See, e.g., Drakeford v. Wilks, 26 Eng. Rep. 1111, 1112 (Chan. 1747), where the chancellor stated that "it is very proper the person who undertook to do the act should perform ... [and the evidence showed that the promisor] declared, she would not defraud the plaintiff, and there is a full evidence likewise of the undertaking, by which she bound her own conscience."

25. "English law has always thought of the constructive trust as an institution ... as opposed to the American attitude that the constructive trust is purely a remedial institution." OAKLEY, supra note 17, at 2 (citations omitted).

26. Avondale Printers and Stationers Ltd. v. Haggie, [1979] 2 N.Z.L.R. 124, 147 (Mahon, J.).

27. See, e.g., Binions v. Evans, [1972] 2 All E.R. 70, 75-77 (C.A. 1972) (Lord Denning, M.R.); LoRD Denning, THE Due Process of LAw 205 (1980); D.W.M. WATERS, The Constructive Trust: The CASE FOR A NEW APPROACH IN ENGLiSH LAW (1964).

28. See 1 PALMER, supra note 17, at 11-12. In other Commonwealth jurisdictions, some variant on the general U.S. view of the constructive trust as a purely remedial device seems to be increasingly accepted. See, e.g., Pettkus v. Becker, [1980] 2 S.C.R. 834 (Can.). There are good comparative studies of English, Commonwealth, and U.S. decisions in B.H. Davis, Implied, Resulting or Constructive Trust?, [1989] DENNING L.J. 52, and Robert L. Stenger, Cohabitants and Constructive Trusts-Comparative Approaches, 27 J. FAM. L. 373 (1988-89).

29. To say that the scope for the exercise of discretion is curtailed is not, of course, to suggest that the judge is deprived of significant discretion in decisionmaking but only that her discretion is directed toward, for example, the establishment of the relevant facts concerning the presence of a fiduciary relationship. 
ended and unpredictable results of adopting a remedy-only view, ${ }^{30}$ and the unabashed policymaking that would be required. ${ }^{31}$

Some early decisions in the United States adopted the emerging English view of the constructive trust as a trust-by-analogy based on the existence of a fiduciary relationship. In Campbell v. Drake, ${ }^{32}$ for example, the plaintiff was the victim of larceny by an employee (Farrow) who subsequently used the proceeds of the theft to purchase land. After Farrow's death, the plaintiff discovered the larceny and sued the heirs for the land, arguing that Farrow should be deemed a trustee for the plaintiff's benefit. The North Carolina Supreme Court accepted the plaintiff's evidence tracing his property to the land ${ }^{33}$ but held that the case was "not at all like the cases of dealings with trust funds by trustees, executors, guardians, factors, and the like, in which the owner of the fund may elect to take either the money or that in which it was invested." In those situations, the injured party could trace her property through different permutations and recover it because "in the nature of his office, and from his relation to the cestui que trust," the defendant owed an accounting of his dealings. The mere fact that Farrow obtained the plaintiff's property through theft, rather than by abusing a confidential relationship, "fully rebuts the idea of converting him into a trustee," and so the court was obliged to dismiss the plaintiff's suit even though "the facts [were] so clearly established, and demands of justice so strong." 35

In the post-Civil War period, the legal conservatism of Campbell v. Drake was matched by decisions stretching the notion of "constructive trust" beyond its English, trust-by-analogy roots. In the 1877 New York case of Newton $v$. Porter, $^{36}$ a court first imposed a constructive trust on the products of larceny; ${ }^{37}$ by the end of the century the very court that decided Campbell held that

a confidential relation is not necessary to establish such [a constructive] trust. . . . The trusts of which we are speaking are not what are known as technical trusts, and the ground of relief in such cases is, strictly speaking, fraud, and not trust.

30. See, e.g., Waters, supra note 17 , at 1216-20, 1224-27, 1253-54.

31. Id. at 1222 (The U.S. unjust enrichment principle suggests, "starkly[,] the choice of policy which the court must make, and the balance it must strike.").

32. 39 N.C. (4 Ire. Eq.) 94 (1845).

33. "[W]e have no doubt, that every cent of the money with which he paid for the land, he pilfered from his employer." Id. at 95.

34. The court distinguished a shop employee from a trustee by noting that the former has neither legal title nor legal possession of the employer's goods and money. Id. The employer, put another way, does not repose the confidence in the employee that a beneficiary extends to a trustee.

35. The court rested its decision in part on the novelty of plaintiff's claim: "Now, we know not any precedent of such a bill. ... If [the law were in the plaintiff's favor], there would have been many a bill of the kind. But we believe, there never was one before; and therefore, we can not entertain this." Id.

36. 69 N.Y. 133 (1877).

37. Professor Dawson identified Newton v. Porter and similar decisions of the late nineteenth century as "the point that most clearly marks the transformation of the constructive trust into a generalized remedial device, with tracing as its most prominent feature." JOHN P. DAWSON, UNJUST ENRICHMENT: A COMPARATIVE ANALYSIS 28 (1951). On Newton, see also 1 PALMER, supra note 17, at $14-15$. 
Equity declares the trust in order that it may lay its hand upon the thing and wrest it from the wrongdoer. ${ }^{38}$

In some U.S. jurisdictions, the courts clearly were transforming the constructive trust from a substantive legal relationship or basis for liability into a remedial device.

In 1920, Roscoe Pound purported to summarize the common U.S. view of constructive trusts as "purely a remedial institution," available "in a variety of situations," including "what we have come to think the typical case of constructive trust, namely specific restitution of a received benefit in order to prevent unjust enrichment." 39 Pound's summary, however, was more a prophecy than a reality. In fact, as Pound somewhat reluctantly acknowledged, some U.S. courts had declined to disassociate the notion of a constructive trust from the presence of a substantive confidential relationship. ${ }^{40}$ Nonetheless, by 1936 , when the American Law Institute promulgated its Restatement of Restitution, the Institute could assume the validity and general acceptability of the remedial approach. ${ }^{41}$ The constructive trust is discussed in a section of the Restatement entitled "Constructive Trusts and Analogous Equitable Remedies." 42 Section 160 , the general definition of the constructive trust, describes it in generally remedial language, ${ }^{43}$ while comment (a) to the section is emphatic.

The term "constructive trust" is not altogether a felicitous one. It might be thought to suggest the idea that it is a fiduciary relation similar to an express trust, whereas it is in fact something quite different from an express trust. An express trust and a constructive trust are not divisions of the same fundamental concept. They are not species of the same genus. They are distinct concepts. A constructive trust does not, like an express trust, arise because of a manifestation of an intention to create it, but it is imposed as a remedy to prevent unjust enrichment.... [T] he circumstances which give rise to a constructive trust may or may not involve a fiduciary relation. ${ }^{44}$

38. Edwards v. Culberson, 111 N.C. 342,345 (1892).

39. Roscoe Pound, The Progress of the Law, 1918-1919: Equity, 33 Harv. L. Rev. 420, 421 (1920).

40. Id. at 421-22 (citing Peixouto v. Peixouto, 181 P. 830 (Cal. Dist. Ct. App. 1919), and Stewart v. Todd, 173 N.W. 619 (lowa 1919)). (Pound tendentiously described the conservative trust-by-analogy view as "this confusion," id. at 422.) Writing from an English perspective, Professor Waters has observed that the term "constructive trust" fits uneasily with the remedial view: "one cannot help thinking that if all unjust enrichment relief in equity is to be brought under the title of constructive trust, why not abandon the term altogether. It is too pregnant with meaning in English law. ... As long as we talk of constructive trust, we are always bound to ask, 'What is the defendant trustee of?"' Waters, supra note 17 , at 1226 .

41. I do not mean to ignore the extent to which the early Restatements often are not so much summaries of existing law as proposals for the appropriate lines of development. See Grant Gilmore, The Death of Contract 61-66 (1974) (discussing $\$ 90$ of the RESTATEMENT OF CONTRACTS).

42. RESTATEMENT OF RESTITUTION 639 (1937). The part links the constructive trust with the equitable lien and subrogation.

43. "Where a person holding title to property is subject to an equitable duty to convey it to another on the ground that he would be unjustly enriched if he were permitted to retain it, a constructive trust arises." Id. $\$ 160$, at $640-41$.

44. Id. $\$ 160 \mathrm{cmt}$. (a). 
The Restatement thus embodies a wholesale rejection of the constructive trust's historical origins in trust-by-analogy situations. ${ }^{45}$ Under the Restatement approach, the focus of judicial enquiry shifts from the establishment of a fiduciary relationship and its abuse to a determination of whether someone has been "unjustly" enriched, and so should be subjected to an "equitable duty" to return the unjust benefit. The conscience of a defendant who stands in some sort of confidential relation to the plaintiff $\mathrm{f}^{46}$ is no longer the only locus of moral decision at issue; indeed, it is the court's view of the equities, the chancellor's conscientious enquiry into the justice of the situation, that determines whether the remedial tool of the constructive trust will be invoked ${ }^{47}$ The defendant "is not compelled to convey the property because he is a constructive trustee; it is because he can be compelled to convey it that he is a constructive trustee." 48

The Restatement suggested several grounds on which a court of equity could decide that one has been unjustly enriched-mistake, fraud, duress and undue influence ${ }^{49}$ - but the comments made it clear that its list was not intended to be exhaustive. ${ }^{50}$ Subsequent case law following the Restatement approach has confirmed the open-ended nature of the remedial understanding of the constructive trust. While some courts have suggested that the remedial approach requires a finding of fraud to justify imposition of a constructive trust, most understand the remedial/unjust enrichment approach as permitting the use of the remedy "in any case where to fail to do so will result in an unjust enrichment." ${ }^{1}$ "Constructive trusts fall into three categories: (1) those arising from actual fraud; (2) those arising from constructive fraud (appropriation of property by fiduciaries or others in confidential relationships); and (3) those based on

45. In light of the emphatic language of $\$ 160$, comment (a), I do not understand Professor Palmer's attribution to the Restatement of "a tendency to treat constructive trust as a substantive legal arrangement, analogous to express trusts." 1 PALMER, supra note 17 , at 17 . But see Dove v. White, 126 A.2d 835, 837 (Md. 1956) (discussing uncertainties in the ALI view as expressed in the Restatements of Restitution and Trusts).

46. I ignore for the moment the fact that the technical defendant need not be the actual fiduciary under the English approach.

47. A "fact situation" may "legitimately be labeled one which justifies a constructive trust, if the court chooses to concentrate on an injustice-a broken confidential relationship or the like." Page $v$. Clark, 572 P.2d 1214, 1217 (Colo. Ct. App. 1977), rev'd on other grounds, 592 P.2d 792 (Colo. 1979). The remedial constructive trust thus is the product of a judicial interpretation of a situation as involving unjust enrichment and demanding relief. See In re Independent Clearing House Co., 41 B.R. 985,999 (Bankr. D. Utah 1984) (constructive trusts "are created by courts of equity and do not come into existence until declared by a court as a means of affording relief").

48. 5 AUSTIN W. SCOTT, THE LAW OF TRUSTS $\$ 462$ (3d ed. 1967).

49. See RESTATEMENT OF RESTITUTION \$\$ 163-171.

50. Id. $\S 160 \mathrm{cmt}$. I: "No attempt is made to cover every situation in which a constructive trust may arise."

51. D'Ippolito v. Castoro, 242 A.2d 617, 619 (N.J. 1968) (disapproving earlier case's apparent requirement of a finding of fraud). Similar statements are legion. See, e.g., Dove v. White, 126 A.2d at 837 (describing the "true rule" to be that "a constructive trust arises under any circumstances which render it inequitable for the holder of the legal title to retain it"). But see National Life Ins. Co. v. Tower, 251 F. Supp. 215, 220 (D. Md. 1966) ("[T]he general rule in the United States . . is that unjust enrichment alone is not a sufficient basis to impose a constructive trust."). Even if the National Life Insurance court's statement was, as a matter of counting jurisdictions, correct in 1966, it is, I believe, clearly incorrect today. 
equitable principles other than fraud." 52 Under this, the purest form of the remedial approach, neither an initial wrongful act by the defendant, nor a mistake, nor the suffering of a loss by the plaintiff is a necessary prerequisite. ${ }^{53}$

The triumph of the remedial view of the constructive trust was neither automatic, nor a matter of logical necessity. ${ }^{54}$ Instead, that triumph has been in part the result of the fact that one of the most famous judges in U.S. legal history, Benjamin Cardozo, ${ }^{55}$ described and advocated the remedial view in a number of opinions, two of which have been cited many times by subsequent U.S. courts. ${ }^{56}$ By memorializing the remedial view in eloquent prose, blessed with the imprimatur of his professional repute, Cardozo enhanced the attractiveness of the remedial view, and influenced the significance of its adoption by U.S. courts. In the next section, this article examines the evidence that Cardozo's formulations have been influential in modern U.S. constructive trust law.

\section{III}

\section{CARDOZO'S RHETORIC AND THE LAW OF CONSTRUCTIVE TRUSTS}

During his tenure as a judge, Benjamin Cardozo wrote opinions in at least fourteen cases in which the availability of a constructive trust was at issue. Two of those opinions, Beatty v. Guggenheim Exploration $\mathrm{Co}^{57}$ and Meinhard v. Salmon,${ }^{58}$ have passed into common professional usage as authorities on the law

52. Slocum v. Hammond, 346 N.W.2d 485, 493 (Iowa 1984) (citations omitted).

53. The statement in Kent v. Klein, 91 N.W.2d 11 (Mich. 1958), is typical:

Fraud in the inception we do not require, nor deceit, nor chicanery in any of its varied guises, for it is not necessary that property be wrongfully acquired. It is enough that it be unconscionably withheld. Nor is it necessary, to move the chancellor's conscience, that plaintiffs have suffered a loss, although in most cases there is both a loss to the plaintiffs and a like gain to the defendant.

Id. at 14 (citations omitted). Accord 5 SCOTT \& FRATCHER, supra note 10, at 313-17.

54. Pound's 1920 remark about "confusion" notwithstanding, the substantive, trust-by-analogy view of constructive trusts is neither confused nor illogical; it is simply a different usage of the term, one that leads to significantly different legal arguments and, at least at times, to different results. (English commentators, to be sure, sometimes dismiss the American remedial view with the same intellectual scorn Pound visited on the substantive approach. See Professor Stenger's quotation of an English academic lawyer's description of Lord Denning's adoption of the American view: "What more vague and woolly formula can there be for dispensing palm-tree justice?" Stenger, supra note 28, at 376 (quoting David J. Hayton, Joseph A. Nathan \& Sir OShley R. Marshall, Cases and COMMENTARY ON THE LAW OF TRUSTS 379 (7th ed. 1980)).

55. On Cardozo's reputation, see POSNER, supra note 15, at 125, arguing that Cardozo's "fame is anchored in a solidly professional reputation. ... It appears that in the opinion of the legal profession, Cardozo is the outstanding American common law judge."

56. The two are Beatty v. Guggenheim Exploration Co., 122 N.E. 378 (N.Y. 1919), and Meinhard v. Salmon, 164 N.E. 545 (N.Y. 1928). Judge Posner has observed that Meinhard is "[t]he most famous of Cardozo's moralistic opinions," and that it is "heavily cited." POSNER, supra note 15, at 104-05. I discuss the fame of the Beatty opinion in the text.

57. 122 N.E. 378 (N.Y. 1919).

58. 164 N.E. 545 (N.Y. 1928). 
of constructive trusts. ${ }^{59}$ This is no doubt in part the result of Cardozo's general prominence, and in part the citation-behavior of U.S. lawyers. It seems clear, however, that the particular, highly rhetorical manner in which Cardozo expressed his view of constructive trusts has played a significant role in the frequency with which his opinions are cited.

In Beatty, Cardozo wrote that

[a] constructive trust is the formula through which the conscience of equity finds expression. When property has been acquired in such circumstances that the holder of the legal title may not in good conscience retain the beneficial interest, equity converts him into a trustee. ... A court of equity in decreeing a constructive trust is bound by no unyielding formula. The equity of the transaction must shape the measure of relief. ${ }^{60}$

These passages are quoted in dozens of later opinions, as well as in many secondary sources; in particular, the first sentence enjoys enormous popularity as a "definition" of the constructive trust. ${ }^{61}$ In Meinhard, Cardozo offered a second "definition": "A constructive trust is, then, the remedial device through which preference of self is made subordinate to loyalty to others."62 Judges and lawyers who cite Beatty and Meinhard seldom discuss or even mention the facts in either case, ${ }^{63}$ and I have not encountered a citation to Beatty that acknowledges that Cardozo's opinion in that case denied a claim for a constructive trust. Cardozo's influence in this area lies not in the holdings of the court for which he spoke, but in the language he used.

The canonization of Cardozo's language began with the Restatement of Restitution promulgated in 1936. As published, the Restatement included detailed Reporter's Notes prepared by Warren A. Seavey and Austin W. Scott. Professors Seavey and Scott's typical note includes an extensive listing of cases analyzed according to factual patterns and outcomes. ${ }^{64}$ The Reporters' Note to the section (section 160) defining the constructive trust, in contrast, begins with the statement that " $[t]$ he remedial character of the constructive trust is brought out by Chief Judge Cardozo in several cases decided by the Court of Appeals of

59. Cardozo's grandiloquent description of the nature of fiduciary obligation in Meinhard is frequently quoted in contexts not involving the constructive trust: "A trustee is held to something stricter than the morals of the market place. Not honesty alone, but the punctilio of an honor the most sensitive, is then the standard of behavior." Meinhard, 164 N.E. at 546.

60.122 N.E. at $380,381$.

61. As of February 10, 1992, Beatty had been cited by over 50 federal decisions and over 200 state cases. The vast majority of these citations involved the quotation of at least the sentence about "the formula through which the conscience of equity finds expression."

62. 164 N.E. at 548 . This "definition" has not been quoted very frequently by later courts (five federal and state quotations as of February 10, 1992). See also RESTATEMENT OF RESTITUTION $\$ 160$ reporters' notes; 5 SCOTT \& FRATCHER, supra note 10, at 303 . Meinhard is very heavily cited on the general issue of fiduciary responsibilities. See POSNER, supra note 15, at 105.

63. See, e.g., 1 PALMER, supra note 17, at 15 (quoting Beatty twice without discussing the facts); 4 id. at 326 (mentioning the facts of Meinhard in less than a sentence).

64. Among a myriad of examples, see the Reporters' Note to section 40 , the general rule on restitution for services rendered. RESTATEMENT OF RESTITUTION at 25-28. 
New York," followed by quotations of the two "definitions" Cardozo offered in Beatty and Meinhard. Nothing is said of the facts or the holdings in either case. The note continues with a single citation to another Cardozo opinion, ${ }^{65}$ and concludes with a long quotation from Roscoe Pound distinguishing express and constructive trusts. ${ }^{66}$

Subsequent case law seconds the ALI Reporters' approval of Cardozo's language. Courts have described the Beatty "definition" of the constructive trust ("the formula through which the conscience of equity finds expression") with a remarkable array of laudatory phrases: "the classical and still timely expression of the constructive trust doctrine is that of then Judge Cardozo",; "the classic definition"; 68 "a classic definition",69 "in a classic statement, Justice Cardozo defined a constructive trust"; 70 "the purpose and spirit of the law of constructive trusts is best stated"; "71 "[t]he . . principle seems to be uniformly recognized and is often cited";2 "this Court has repeatedly cited with approval the oftquoted language of Justice (then Judge) Cardozo"; 73 "the philosophy behind the theory of the constructive trust is best summed up by Judge Cardozo"; $;$ " $[t]$ his imposing of a constructive trust is entirely in accord with the precepts of equity. As Cardozo J once put it." 75 The beauty of Cardozo's language is often noted: "[i]n a felicitous and much quoted phrase, Judge Cardozo said"; "76 "[a]s Justice Cardozo so eloquently put it"; "77 "the conception . . . was aptly stated by Judge Cardozo"; "[a]s usual, Judge Cardozo expressed its vague contours most eloquently"; $;$ "Justice Cardozo tellingly stated the inherent qualities of a constructive trust. ${ }^{\prime 80}$ Cardozo, indeed, sometimes is credited incorrectly with

65. Melenky v. Melen, 134 N.E. 822 (N.Y. 1922). Seavey and Scott did append a parenthetical to the cite giving the result, although without explaining it. RESTATEMENT OF RESTITUTION at 198.

66. The Reporters' Note to $\S 160$ is at 198-99. (The Pound article Seavey and Scott quote is Pound's 1920 piece cited supra note 39, at 14.)

67. In re Mid-Center Redevelopment Corp., 383 F. Supp. 954, 971 (D.N.J. 1974).

68. National Life Insurance Co. v. Tower, 251 F. Supp. 215, 219 (D. Md. 1966).

69. Ellis v. Schwank, 223 P.2d 448, 450 (Wash. 1950).

70. In re Independent Clearing House Co., 41 B.R. 985, 999 (Bankr. D. Utah 1984).

71. Spinner v. Fulton, 777 F. Supp. 398, 402 (M.D. Pa.), affd, 947 F.2d 937 (3d Cir. 1991).

72. Malone v. Gimpel, 151 F. Supp. 549, 554 (N.D.N.Y. 1956).

73. Stauffer v. Stauffer, 351 A.2d 236, 241 (Pa. 1976). See also 1 PALMER, supra note 17, \& 1.3, at 15 ("Judge Cardozo's frequently quoted statement").

74. Fain v. Beaver, 478 S.W.2d 816, 818-19 (Tex. Civ. App. 1972).

75. Binion v. Evans, [1972] 2 W.L.R. 729, 735 (Lord Denning, M.R.). A New Zealand academic lawyer recently wrote of Binion that in it "Lord Denning had the audacity to cite a generalization made by Cardozo J." Davis, supra note 28 , at 61 .

76. Dolmetta v. Uintah Nat'l Corp., 712 F.2d 15, 18 (2d Cir. 1983).

77. TMG II v. United States, 778 F. Supp. 37, 46 (D.D.C. 1991).

78. Doing v. Riley, 176 F.2d 449, 457 (5th Cir. 1949).

79. Rollins v. Metro. Life Ins., 912 F.2d 911, 914 (7th Cir. 1990). Cf. Sharp v. Kosmalski, 351 N.E.2d 721, 723 (N.Y. 1976) (where, on the same page on which the court quoted the second sentence in the Beatty "definition," it introduced a famous sentence from another Cardozo opinion, Wood v. Lucy, Lady Duff-Gordon, 118 N.E. 214 (N.Y. 1917)), with the words, "[a]s Judge Cardozo so eloquently observed."

80. Thomasi v. Koch, 660 P.2d 806, 810 (Wyo. 1983). Cf. Nelson v. Johnson, 212 F. Supp. 233, 288 (D. Minn. 1963) ("The stirring phrases of Judge Cardozo are indelibly written into the law for posterity. Among his never-to-be-forgotten words are those in Meinhard v. Salmon [quoting the passage about 'the 
introducing the remedial view of the constructive trust. ${ }^{81}$ A citation to the Beatty "definition" is almost a standard feature of a modern U.S. opinion dealing with constructive trust law. ${ }^{82}$

Cardozo's descriptions of the constructive trust, especially the "definition" in Beatty, frequently appear in post-Second World War U.S. judicial opinions, as well as in the scholarly works that collect and comment upon those opinions. But what is the significance of that fame? As already noted, contemporary judges almost never refer to the facts or holdings of Cardozo's constructive trust cases. ${ }^{83}$ It is Cardozo's language, his turns of phrase, that play an important role in the modern U.S. law of constructive trusts. What, then, do Cardozo's words say, divorced from their original setting in his attempt to resolve particular controversies?

The most frequently quoted language is the Beatty definition. ${ }^{84}$ Taken on its own, this sentence neither defines nor explains the term "constructive trust." It, rather, expresses an attitude, a determination to bring the conscience of the decisionmaker to bear on the dispute before the court. ${ }^{85}$ Read in isolation, the sentence exhorts the equity judge to do substantive justice without giving any substantive content to the exhortation.

punctilio of an honor the most sensitive'].").

81. See, e.g., Voest-Alpine Trading USA v. Vantage Steel Corp., 919 F.2d 206, 216 (3d Cir. 1990) ("The imposition of a constructive trust as a remedy dates back at least to Beatty v. Guggenheim Exploration Co."). The Reporter's Notes to $\S 160$ of the Restatement of Restitution probably bear part of the responsibility for this mistaken historical understanding.

82. Cardozo's writ runs to every region and most states. See, e.g., American Family Care, Inc. v. Irwin, 571 So. 2d 1053, 1058-59 (Ala. 1990); Raestle v. Whitson, 582 P.2d 170, 172 (Ariz. 1978); Heckmann v. Ahmanson, 214 Cal. Rptr. 177, 189 (Cal. Ct. App. 1985); Page v. Clark, 592 P.2d 792, 798 (Colo. 1979); Starzec v. Kida, 438 A.2d 1157, 1162 (Conn. 1981); Penn Mutual Life Ins. Co. v. Abramson, 530 A.2d 1202, 1213 (D.C. 1987); Small v. Badenhop, 701 P.2d 647, 655 (Hawaii 1985); Witt v. Jones, 722 P.2d 474, 483-84 (Idaho 1986) (Bistline, J., dissenting); Cohon v. Oscar L. Paris Co., 149 N.E.2d 472, 47677 (Ill. App. Ct. 1958); Witmer v. Estate of Brosins, 336 P.2d 455, 460-61 (Kan. 1959); Superior Glass Co. v. First Bristol Co. Nat'l Bank, 394 N.E.2d 972, 974-75 (Mass. App. Ct. 1979); Michigan Bank, Nat'l Assoc. v. Kahlich, 179 N.W.2d 29, 30 n.2 (Mich. Ct. App. 1970); Stovall v. Stovall, 67 So. 2d 391, 405 (Miss. 1953) (Ethridge, J., dissenting); Stratton v. Stratton, 694 S.W.2d 510, 512 n.1 (Mo. Ct. App. 1985); Campbell v. Kirby, 239 N.W.2d 792, 797 (Neb. 1976); Milne v. Burlington Homes, Inc., 379 A.2d 198, 199-200 (N.H. 1977); Carr v. Carr, 576 A.2d 872, 880 (N.J. 1990); Atkinson v. Atkinson, 33 S.E.2d 666, 671 (N.C. 1945); Bodding v. Herman, 35 N.W.2d 561, 563 (N.D. 1948); Banasiak v. Banasiak, 1981 WL 5650 (Ohio Ct. App.), at 2; Hughes v. Helzer, 185 P.2d 537, 544 (Ore. 1947); Truver v. Kennedy, 229 A.2d 468, 474 (Pa. 1967); Central Bus Lines v. Hamilton Nat'l Bank, 239 S.W.2d 583, 585 (Tenn. Ct. App. 1951); Andrews v. Andrews, 677 S.W.2d 171, 173 (Tex. Ct. App. 1984); State Dept. of Revenue v. Puget Sound Power \& Light Co., 694 P.2d 7, 15 (Wash. 1985); Nelson v. Johnson, 212 F. Supp. 233, 288 (D. Minn.1963) (federal common law of remedies).

83. The exception, unsurprisingly, is New York, where Cardozo's majority opinions for the state court of appeals are directly authoritative. See, e.g., Sharp v. Kosmalski, 351 N.E.2d 721, 723-24 (N.Y. 1976) (quoting briefly from the facts in Sinclair v. Purdy, 139 N.E. 255, 258 (N.Y. 1923) (Cardozo, J.)). The Sharp court, however, quoted a sentence from Beatty without discussing facts or holding.

84. See supra notes $59-61$ and accompanying text.

85. I am aware that Cardozo actually ascribes the role of moral decisionmaking not to the judge but to "equity." Although something could undoubtedly be made of Cardozo's use of such rhetoric to distance himself from the act of moral decisionmaking, in this context, I am not convinced that his usage is more than one more expression of his preference for heightened rhetoric. But see JOHN T. NOONAN, PERSONS AND MASKS OF THE LAW (1976), for a different interpretation of Cardozo's use of rhetoric. 
The next sentence in Beatty, which is also frequently quoted, adds content, but not much: "When property has been acquired in such circumstances that the holder of the legal title may not in good conscience retain the beneficial interest, equity converts him into a trustee." 86 This statement defines the constructive trust as a remedial tool rather than a substantive legal relationship; if the defendant ought not to keep the property, then he becomes a constructive "trustee" for the sole purpose of giving the property up. Nothing is said about what grounds would suffice for concluding that the defendant cannot retain the property "in good conscience," and, indeed, the sentence is remarkably ambiguous as to whose conscience is to be engaged. Taken by itself, the sentence seems to refer to the conscience of the person holding the property, but in the context of the preceding statement about the "conscience of equity," the reader is left unsure about just whose moral decisions are in question, the defendant's or the judge's. The two sentences, read together, urge upon the judge the duty and prerogative of shaping the court's response to accord with the judge's moral vision-the chancellor's conscience. ${ }^{87}$ They say little or nothing about what education, commitments, or beliefs should inform that conscience. ${ }^{88}$

Cardozo's second ostensible "definition" of the constructive trust, contained in the Meinhard opinion, is quoted much less frequently by courts. ${ }^{89}$ Some courts find the Meinhard definition too narrow, applicable only to situations involving the breach of a confidential relationship. ${ }^{90}$ Read out of context, as Cardozo's statements about constructive trusts seem almost always to be, his statement in Meinhard may be unpopular because it has too much substance.

86. 122 N.E. at 380 .

87. The same studied ambiguity marks the other famous passage in Beatty. Having concluded that the supposedly injured party had in fact consented to the alleged wrongdoer's action, Cardozo wrote that "good conscience no longer demands that the agent be charged as a trustee. A court of equity in decreeing a constructive trust is bound by no unyielding formula. The equity of the transaction must shape the measure of relief." Id. These clauses place "good conscience" in parallel with "[a] court of equity" and "[t]he equity of the transaction." Even if this "good conscience" is still, logically or syntactically, that of the alleged wrongdoer, the overall impression the passage communicates, I think, is that it is the judge who must apply his or her sense of equity to "shape the measure" of the court's response.

88. Occasionally a judge appears uneasy with the essential emptiness of the Cardozo rhetoric he or she has quoted. In Page v. Clark, for example, the court prefaced quotations of the Beatty and Meinhard "definitions" with the statement that the constructive trust "is governed by broad principles which have been refined by centuries of use into specific remedies"; the court immediately followed the quotations with a sentence beginning, "[t]hese maxims have been given force in particular cases through the development of rules." 592 P.2d 792, 797, 798 (Colo. 1979).

89. See supra text accompanying notes $62-63$.

90. See, e.g., Witmer v. Estate of Brosius, 336 P.2d 455, 460 (Kan. 1959). After quoting the Meinhard language, the court stated that "[t]his is not and undoubtedly was not intended to be a definition of a constructive trust, since it includes only those which arise out of an abuse of a fiduciary relation." The court then proceeded to quote the Beatty formulation and describe it as "a more nearly complete description of a constructive trust." Id. at 461.

Seavey and Scott, the Reporters of the Restatement of Restitution, seem to have read Meinhard more broadly. They quoted the Meinhard formulation in the Reporter's Notes apparently to illustrate the general proposition that the constructive trust is a remedial device (see the discussion, supra, at text accompanying notes $42 \& 43$ ) while stating in the comments that a constructive trust situation "may or may not involve a fiduciary relation.” RESTATEMENT OF RESTITUTION $\$ 160 \mathrm{cmt}$. a, at 641 . 
Unlike the Beatty definition, which tells the judge little except to do justice, Meinhard seems to demand that the chancellor enforce too stringent a standard of behavior, to compel the defendant to subordinate the self to the other. While such a demand, carefully qualified, is part of the law of fiduciary obligation, it clearly is not an appropriate standard for determining when unjust enrichment exists and should be corrected in a market economy of the modern Western variety. Taken for all they are worth, Cardozo's words in Meinhard undermine the individualistic premises on which mainstream U.S. notions of "justice" and "good conscience" are based.

An exhortation to moral decision, ambiguous invocations of "conscience," an all-too-radical call for self-abnegation"1_Cardozo's "influence" on the modern U.S. law of constructive trusts is, it seems, "rhetorical" in the negative, evaluative sense of the word. Except to the extent that his fame and the perceived beauty of his words have played a role in overcoming resistance to the remedial view, it is very difficult to perceive what Cardozo has contributed to constructive trust law beyond some colorful language. Indeed, a latter-day John Selden might go further and argue that Cardozo's "contribution" has been essentially pernicious, that Cardozo's words and fame have served to license a particularly lawless form of equitable discretion, and that Cardozo exemplifies what is wrong with the chancellor's-foot approach to justice. ${ }^{92}$ But is it possible that the modern U.S. judicial tradition has misread Cardozo? Was there more to his view of the constructive trust than an assertion of moral choice?

IV

\section{CARDOZO'S CONSCIENCE IN CONTEXT}

In The Nature of the Judicial Process, Cardozo included what he called "the method of sociology" among the forms of reasoning judges employ in deciding cases. ${ }^{93}$ Under this somewhat misleading rubric, Cardozo discussed the considerations of social welfare that judges take into account in reaching decisions. Cardozo applauded the exercise of judicial power in accordance with the judges" "insight into social values, and with suppleness of adaptation to changing social needs." 94 "Social welfare," for Cardozo, was "a broad term. I use it to cover many concepts more or less allied." He identified one branch

91. Compare Cardozo's description of the defendant, a paragraph after his Meinhard definition: "Salmon had put himself in a position in which thought of self was to be renounced, however hard the abnegation.” 164 N.E. at 548.

92. Critics of Lord Denning for his introduction of the U.S. remedial constructive trust into English case law (among other sins) often make such arguments about the former Master of the Rolls. See Davis, supra note 28, at 53-58,61-62; Stenger, supra note 28, at 375-77.

93. Benjamin N. Cardozo, The Nature of the Judicial Process (1921), in SELeCted WRITINGS OF BENJAMIN NATHAN CARDozo 135 (Margaret E. Hall ed., 1947) [hereinafter SElECTED WRITINGs].

94. Id. at 144. Cardozo disapproved of the substantive due process jurisprudence of the Lochner Court, not because the Justices were bringing their views of social welfare to bear on their decisions, but because their views were, in Cardozo's view, antiquated. Id. at 137-40. 
of social welfare as

the social gain that is wrought by adherence to the standards of right conduct, which find expression in the mores of the community. In such cases, its demands are those of religion or of ethics or of the social sense of justice, whether formulated in creed or system, or immanent in the common mind. ${ }^{95}$

While Cardozo did not have equity specifically in mind in this discussion, the views he expressed there frequently are evident in his opinions in equity cases. As Judge Posner observed in his book on Cardozo's reputation, "[e]quity cases are rich in examples of a fruitful merger of morality and law"; Cardozo's "moralizing tendency" in decisionmaking unsurprisingly led him to insist "on the importance of equity and construe the equity powers of the New York courts broadly." 96

Cardozo's equity opinions, as a body, have several marked characteristics. They are, first, unabashed in moral judgments on the parties. "Neither principle nor precedent supports the decree of absolution thus granted to a wrongdoer."97 "The Southern Corporation did not limit its wrongdoing to the corruption of the plaintiff's agents." ${ }^{88}$ "To avoid misconstruction, it should be said that the petitioning creditors and their attorney, and the receiver and his attorneys, acted throughout the proceeding in good faith, and they are not subject to any criticism." Cardozo's statements of the facts were shaped in large measure by his interpretation of their moral significance. Describing an apparent attempt to conceal a bankrupt's assets from creditors, Cardozo wrote that "there was the gesture of public sale ... the form of an auction ... to make the job a thorough one, the odds and ends of other assets were to be conveyed to friends or relatives." 100

A second characteristic of Cardozo's opinions is his repeated emphasis on the power of the court of equity to require adherence to moral principles, even those requiring affirmative action on the part of someone. "There is no undeviating principle that equity shall enforce the covenants of a mortgage, unmoved by an appeal ad misericordiam, however urgent or affecting. . . . Equity . . . compels the buyer to exhibit an involuntary charity if he is found to have taken advantage of the necessities of the seller."101 Where someone has "put himself in a position in which thought of self was to be renounced," the equity court would hold him to the renunciation, "however hard the abnegation."102

95. Id. at 135 .

96. POSNER, supra note 15 , at 105 . The reference to Cardozo's "moralizing tendency" is in id. at 98-99.

97. Evangelical Lutheran Church of the Ascension v. Sahlem, 172 N.E. 455, 458 (N.Y. 1930).

98. Marr v. Tumulty, 175 N.E. 356,357 (N.Y. 1931).

99. Drucklieb v. Harris, 147 N.Y.S. 298, 302 (N.Y. Sup. Ct. 1914).

100. Buffum v. Peter Barceloux Co., 289 U.S. 227, 230, 233 (1933).

101. Graf v. Hope Bldg. Corp., 171 N.E. 884, 886-87 (N.Y. 1930) (Cardozo, C.J., dissenting).

102. Meinhard, 164 N.E. at 548. 
A third characteristic of Cardozo's equity opinions is his insistence on the fact-specific nature of the chancellor's decisions. "When an advantage is unconscionable depends upon the circumstances. ... always the gravity of the fault must be compared with the gravity of the hardship."103 "Though a promise in words was lacking, the whole transaction, it might be said, was 'instinct with an obligation' imperfectly expressed. It was to be interpreted, not literally or irrespective of its setting, but sensibly and broadly with all its human implications." 104 Cardozo's intense awareness of the variability of human affairs lay at the heart of his frequent statements about the flexibility of equity: "The plastic remedies of the chancery are moulded to the needs of justice."105 Equity's central characteristic, for Cardozo, is its ability to answer "the call of the occasion." 106

Cardozo's stress on the uniqueness of the individual case, and on the corresponding particularity of the chancellor's decisions, ${ }^{107}$ was not, in his mind, a prescription for the "Chancellor's foot" justice Selden feared. ${ }^{108}$ "In the award of equitable remedies there is often an element of discretion, but never a discretion that is absolute or arbitrary. In equity, as at law, there are signposts for the traveller." 109 Those signposts were, for Cardozo, the "customary morality, the prevailing standard of right conduct, the mores of the time."110 The law, and especially the law of equity, is to embody and enforce "so much of morality as the thought and practice of a given epoch shall conceive to be appropriately invested with a legal sanction." 111 The equity judge sits to apply the shared morality of the community and not to impose his or her private moral views, or even those societal ideals that are understood as aspirations rather than commands. "The judge ... finds his moral value through his readings of the social mind." 112 This did not imply, Cardozo insisted, that judges can or should reflect only the most conservative or status-quo interpretation of the community's mores. The law is in fact one of the means by which social morality advances, even if the role of judges in that advance must be incremental. ${ }^{113}$

103. Graf, 171 N.E. at 888.

104. Sinclair v. Purdy, 139 N.E. 255, 258-59 (N.Y. 1923) (citations omitted).

105. Foreman v. Foreman, 167 N.E. 428,429 (N.Y. 1929). The best known such statement is, of course, in Beatty: "A court of equity in decreeing a constructive trust is bound by no unyielding formula. The equity of the transaction must shape the measure of relief." 122 N.E. at 381.

106. Adams v. Champion, 294 U.S. 231, 237 (1935).

107. See, e.g., Meinhard, 164 N.E. at 547 ("Little profit will come from a dissection of the precedents. None precisely similar is cited in the briefs of counsel.").

108. Cardozo, indeed, was familiar with the Table Talk and once described Selden as "one of the ancient sages of our law." Benjamin N. Cardozo, Law and Literature, in SELECTED WRITINGS, supra note 93 , at 371 .

109. Evangelical Lutheran Church, 172 N.E. at 457.

110. Benjamin N. Cardozo, The Nature of the Judicial Process, in SELECTED WrITINGS, supra note 93, at 132.

111. Benjamin N. Cardozo, The Paradoxes of Legal Science, in SELECTED WRITINGS, supra note 93, at 276-77.

112. Id. at 283.

113. Id. at 277 . 
Cardozo once wrote that, in "find[ing] his moral value," the judge "goes to the same source from which values generally are born, consults the same book that is spread open to us all."114 Nevertheless, Cardozo clearly did think that part of that "book" was peculiarly legal—-the opinions of great judges. Cardozo, of course, was an unusually self-conscious judicial stylist; ${ }^{115}$ this was the product, in part, of his belief in the educational role of judicial opinions. Judge Posner has written that "[ $\mathrm{t}]$ he primary impact of Cardozo's work, both judicial and nonjudicial, may well have been pedagogical in the best sense."116 The observation, as a statement of one of Cardozo's goals, seems to me quite correct. Addressing a graduating law school class in 1925, Cardozo described the lawyer's continuing self-education as involving the study of "the wisdom of the past, for in a wilderness of conflicting counsels, a trail has there been blazed."117 At least some of that wisdom, for Cardozo, lay in the opinions in which wise judges explain their resolution of the disputes "conflicting counsels" presented them. Three years later, Cardozo told another group of law graduates that the law involves "directing desires ... rationalizing hopes and fears ... shaping and guiding character."118 Cardozo's opinions were meant to play a part in this process of moral education. His own "chancellor's conscience" formed by his professionalization into the law, by reading and reflection on the opinions of other judges, wise and foolish, Cardozo sought to influence the moral commitments and to shape the character of other lawyers and judges who would read his opinions. Cardozo's opinions often address the reader in an imperative voice. "Whoever is a fiduciary or in conscience chargeable as a fiduciary is expected to live up to them."119 The process of judicial decisionmaking, which Cardozo described in his extrajudicial writings and enacted in his judging, was not for Cardozo a free-form activity of choice; it was, rather, an engagement in a moral tradition that had shaped decisively Cardozo's own moral vision as well as his understanding of the facts, the moral equities, and the legal doctrines involved in any given case. Cardozo's opinions were intended to carry on that tradition by shaping the vision and understanding of other lawyers and judges.

Cardozo's constructive trust opinions are particularly clear examples both of Cardozo's participation in the moral tradition of the law, and of his effort to provide new instruction in that tradition. As already observed, Cardozo's presentation of the facts and issues evidences his view of the moral equities of

114. Id. at 283 .

115. In addition to his opinions, see Cardozo's taxonomy of opinion-writing styles in Law and Literature, in SELECTED WRITINGS, supra note 93, at 339-54, and his essay entitled Mr. Justice Holmes, which focuses attention on Holmes's writing, in id. at 83-86.

116. POSNER, supra note 15, at 126. Judge Posner, of course, is himself a noted and distinctive stylist in opinion-writing.

117. Benjamin N. Cardozo, Law and Literature, in SELECTED WRITINGS, supra note 93, at 421.

118. Benjamin N. Cardozo, Our Lady of the Common Law, in SELECTED WRITINGS, supra note 93, at 95 .

119. Buffum v. Peter Barceloux Co., 289 U.S. 227, 237 (1933) (emphasis added). 
the controversy before him. ${ }^{120}$ Rather than relying on the formulaic statements of the equitable principles he was so adept at crafting, Cardozo is at pains in his opinions to make clear why, under the circumstances of the particular case, someone has been treated unfairly or someone else enriched unjustly. ${ }^{121}$ Furthermore, Cardozo repeatedly invites the reader to apply common moral, ${ }^{122}$ familial, ${ }^{123}$ and social ${ }^{124}$ expectations and commitments. Cardozo's opinions instruct the reader by providing her with examples of good and bad behavior, as well as (or so Cardozo hopes) wise moral evaluation and decisionmaking.

Beatty v. Guggenheim Exploration Company, the source of so many contextless quotations in the opinions of other judges, exemplifies Cardozo's own nuanced, deeply contextual approach to constructive trust cases. Cardozo's opinion was delivered after the case was reargued. The New York Court of Appeals initially reversed the Appellate Division's judgment in the plaintiff's favor. ${ }^{125}$ The high court imposed a constructive trust on behalf of the company (the actual defendant) on certain funds held by a third party (Perry, a nominal defendant) and remanded the cause for a new trial concerning other funds claimed by the plaintiff. ${ }^{126}$ Reargument addressed the question of whether the second claim could be determined on the merits as well. ${ }^{127}$ In an opinion for a five-justice majority, Cardozo ruled for the plaintiff on that claim.

Cardozo began by carefully separating the issue before the court from the claim already decided. In its earlier opinion, he wrote, the court determined that the plaintiff had persuaded Perry

to ask for more pay [from the Company, their mutual employer] than would otherwise have satisfied him, in order that plaintiff might get a share of it. We held that this was a breach of the plaintiff's duty to his employer. The payment, thus unlawfully swollen, was subject to a constructive trust. ${ }^{128}$

120. See, e.g., Drucklieb v. Harris, 147 N.Y.S. 298, 299-302 (Sup. Ct. 1914), a masterpiece of sustained irony that leaves no doubt in the reader's mind that Cardozo believed the defendant a scoundrel-and that that moral judgment should be the reader's as well.

121. In Meinhard v. Salmon, 164 N.E. 545 (N.Y. 1928), for example, after a careful presentation of the facts and of the general moral and legal characteristics of joint ventures, Cardozo writes that "[t]he trouble about [the defendant's] conduct is that he excluded his coadventurer from any chance to compete, from any chance to enjoy the opportunity for benefit that had come to him [the defendant] alone by virtue of [the joint venture]." Id. at 547. Cardozo's constructive trust opinions generally state directly and clearly what Cardozo finds morally troublesome (or not) about the parties' conduct.

122. See, e.g., id. at 548 (supporting conclusion that the defendant acted unjustly in procuring a new lease for himself with the assertion that he "might fairly expect to be reproached with conduct that was underhand ... if the partner were to surprise him in the act of signing the new instrument").

123. See, e.g., Sinclair v. Purdy, 139 N.E. 255, 257 (1923) (interpreting an ambiguous letter against the "background" of the family relationship of the writer and recipient).

124. See, e.g., Whiting v. Hudson Trust Co., 138 N.E. 33, 37 (N.Y. 1923) ("The transactions of banking in a great financial center are not to be clogged, and their pace slackened, by overburdensome restrictions.").

125. 153 N.Y.S. 757 (App. Div. 1915).

126. 119 N.E. 575 (N.Y. 1918). Cardozo did not sit on this round of the appeal.

127. The reargument order is at 121 N.E. 855 (N.Y. 1918).

128. 122 N.E. at 379. 
The defendants argued that the second set of funds, profits Perry and the plaintiff had realized from the sale of interests they had obtained in property which the company actually bought, should also be subjected to a constructive trust. The two claims, they said, were "inseparably united in scheme and execution." Cardozo, however, disagreed. "[T]he payment for Perry's services is quite distinct from the payment of Perry's profits in the sale," he wrote, because the two transactions concerned different interactions and "[i]ncrease of the one had no tendency to swell the measure of the other." Only after establishing this factual basis for his decision to treat the claims separately did Cardozo state a legal principle: "Subsequent misconduct in another and distinct transaction does not work a forfeiture of rights already lawfully accrued." 129

The question then became, Cardozo wrote, whether the plaintiff ever "lawfully" acquired a right to the profits at issue. He reasoned that unless the company agreed otherwise, the plaintiff would be bound to turn over the profits because he was an agent and in an "intimate relation" with a trusting employer. ${ }^{130}$ While expressing the view that "it may fairly be found that there was a diversion of profits [from the company] here," Cardozo found that issue nondispositive because of the close connection between the company's business and the plaintiff's speculations. In this context, Cardozo wrote his famous "definition." 131 In context, therefore, the words about "the conscience of equity" were not a comprehensive description of the remedy, but a rejection of the specific legal argument that a diversion of profits from the injured party must be found to justify a constructive trust.

Cardozo then turned to the question of whether the company had agreed to permit the plaintiff's speculation. The starting point of the analysis was the observation that "the Appellate Division has found upon sufficient evidence that the employer consented to the investment," ${ }^{132}$ a fact that Cardozo believed would reverse the equities in an ordinary case and deny the company a right to the plaintiff's profits. The problem was that the consent was oral; the plaintiff's employment contract released him from its noncompetition clauses only on written waiver. But the contract's arrangement of the parties' relation, Cardozo reasoned, had been altered in this respect by the fact that the company did not insist on its rights when the plaintiff could avoid a loss.

The plaintiff had reserved the right to withdraw from the joint enterprise if his employer disapproved of it, and in that event to treat his advances as a loan. On the faith of the consent, he turned a loan into a purchase. It is too late, years afterwards, for the employer to cancel the consent, and insist that the purchase be turned back into a loan. ${ }^{133}$

129. Id.

130. In typical fashion, Cardozo appealed to the reader's own sense of common notions of fairness. See the passage in id. at 380 beginning "Let us suppose."

131. Id.

132. Id.

133. Id. at 381 . 
The same conclusion would follow, Cardozo continued, even if one viewed the oral consent as ineffective to modify the contract. On that interpretation, the company's knowing decision to permit the plaintiff to go ahead with the speculation was in effect an election not to pursue its remedies under the contract. "After an election so decisive, announced while there was still an opportunity to withdraw, good conscience no longer demands that the agent be charged as a trustee." It was in this context, that of denying the company's claim to a constructive trust, that Cardozo made the famous statement that "[t]he equity of the transaction must shape the measure of relief."134

Beatty is typical of Cardozo's constructive trust opinions. It is rich in factual detail, in moral judgments, in invitations to the reader to test Cardozo's arguments in the forum of conscience, and (implicitly) to allow her conscience to be shaped by Cardozo's moral vision of the facts, and of the social world as a whole. The empty generalizations that courts frequently draw from the opinion are far from empty in context; there they are filled with Cardozo's application of his chancellor's conscience, formed by the common mores of his society, and especially of that society's legal tradition, to the particular facts of the case. ${ }^{135}$ The "Cardozo" that modern judges ritualistically cite for the "classic definition" of the constructive trust is not the historical Cardozo, a judge acutely aware of "the repression of a formula, the tyranny of tags and tickets," 136 and their use of his opinions as a source of such formulas is an ironic inversion of the actual man's understanding of how to read and use judicial opinions. ${ }^{137}$

\section{$\mathrm{V}$ \\ CONCLUSION}

It may not be accidental that post-Second World War U.S. judges so misuse Cardozo's constructive trust opinions. Those opinions, like Cardozo's writings generally, depend for their very sense on certain assumptions about law that contemporary lawyers do not share. Cardozo assumed the existence of a moral tradition, within the legal profession and in society generally. He assumed that the existence of that tradition, while it did not eliminate change or conflict, ${ }^{138}$ provided a common set of moral commitments that rendered change comprehen-

134. Id.

135. Compare, for example, Cardozo's treatment of the moral and legal significance of the oral consent in Beatty with his discussion, leading to the opposite conclusion, in Rogers v. Guaranty Trust Co., 288 U.S. 123, 150 (1933) (dissenting opinion).

136. Benjamin N. Cardozo, Mr. Justice Holmes, in SELECTED WRITINGS, supra note 93, at 83.

137. The reduction of Cardozo's constructive trust opinions to formulas or slogans is a specific example of a more general problem in contemporary U.S. equity jurisprudence. See, for example, the acute observations of Justice William T. Quillen in Roland International Corp. v. Najjar, 407 A.2d 1032, 1037-1040 (Del. 1979) (dissenting opinion).

138. See, e.g., Cardozo's discussion of change in the law in Paradoxes of Legal Science, in SELECTED WRITINGS, supra note 93, at 257-68. 
sible and confict resolvable. He assumed that to order society and administer the law, it was necessary for public persons, including lawyers and judges, to allow their characters to be shaped by a shared tradition. For Cardozo, the chancellor's discretion to do justice was not to be equated with the arbitrary choices of an autonomous free will. In a deep sense, Cardozo did not see his decisions as matters of choice at all, but rather as attempts truthfully to describe and respond to the situations brought before him.

We live in a different world than the one Benjamin Cardozo believed he inhabited. ${ }^{139}$ In his world, the informed conscience of the chancellor was free to exercise discretion in judgment because his decisions were embedded in a tradition that made discretion rational rather than arbitrary, more an act of solidarity than an expression of individual choice. ${ }^{140}$ In our world, the ancient demand of equity to do substantive justice is more likely to be what Selden feared: a license to wield power in accord with individual taste, to measure justice by the length of the Chancellor's foot.

139. I am unsure to what extent (if any) Cardozo himself was mistaken on this matter. His opinions seem to reflect little of the breakdown of moral consensus in the United States: In them we hear a consistent, almost serene voice confident that it can appeal to the shared sensibilities of colleagues, parties, readers, and the world at large. I am uncertain about how to evaluate the fact that we also hear the voice of a moderate, commercially oriented, mildly progressive Northeasterner of cultured tastes. Today, at any rate, Cardozo does not express a moral tradition shared within U.S. society or even the legal profession.

140. In this respect, Cardozo himself was a faithful student of the creators of modern English equity. "With such a conscience as is only naturalis et interna, this Court has nothing to do; the conscience by which I am to proceed is merely civilis et politica." Cook v. Fountain, 36 Eng. Rep. 984, 990 (Chan. 1672) (Lord Nottingham). 
